\title{
Erratum to: Temperature Measurement Challenges and Limitations for In-Flight Particles in Suspension Plasma Spraying
}

\author{
Bishoy Aziz $^{1}$ Patrick Gougeon ${ }^{2} \cdot$ Christian Moreau $^{1}$
}

Published online: 28 March 2017

(C) ASM International 2017

\section{Erratum to: J Therm Spray Tech}

DOI 10.1007/s11666-017-0543-8

We regret that the original article contained an outdated affiliation for Dr. Patrick Gougeon. His affiliation should have been updated to read: Saguenay, QC, Canada.

The online version of the original article can be found under doi:10.1007/s11666-017-0543-8.

Bishoy Aziz

Bishoysamwel@hotmail.com

Christian Moreau

christian.moreau@concordia.ca

1 Department of Mechanical and Industrial Engineering,

Concordia University, Montreal, Canada

2 Saguenay, QC, Canada 